\title{
Impact of abdominal fat and insulin resistance on arterial hypertension in non-obese women
}

\author{
Impacto da gordura abdominal e resistência à insulina \\ na hipertensão arterial em mulheres não-obesas
}

Eliana A. Silva' ${ }^{1}$ Fernando Flexa', Maria Teresa Zanella

'Departamento de Endocrinologia, Universidade Federal de São Paulo (Unifesp), São Paulo, SP, Brazil
Correspondence to:

Eliana A. Silva

Rua Loefgreen, 1.291, cj. 101-102 Vila Clementino

04040-031 - São Paulo, SP, Brasi eliapsilva@uol.com.br

Received in Apr/21/2008 Accepted in Jan/14/2009

\begin{abstract}
Objective: To evaluate the impact of abdominal fat and insulin resistance on arterial hypertension of non-obese women. Methods: Thirty-five non-obese women (NO), age 35-68 years were studied, and divided into two groups according to the presence of hypertension (BP $\geq 140 \mathrm{x}$ $90 \mathrm{mmHg}$ ) ( HT = hypertensive; NT = normotensive). Leptin measurement and oral glucose tolerance test (OGTT) to assess insulin were performed in these patients. A CT-scan was used to evaluate visceral (VF) and subcutaneous abdominal fat (SCF). The Central fat distribution index (CDI) was proposed to evaluate the impact of subcutaneous abdominal fat on central fat distribution in hypertensive patients. Results: When compared to NT-NO $(n=17)$ group, HT-NO $(n=18)$ showed higher blood pressure levels (systolic and diastolic), greater VF area ( $84.40 \pm 55.70$ versus $\left.37.50 \pm 23.00 \mathrm{~cm}^{2} ; p=0.036\right)$, greater SCF area $\left(174.30 \pm 83.00\right.$ versus $\left.79.80 \pm 27.40 \mathrm{~cm}^{2} ; p=0.030\right)$, higher HOMAr index $\left(1.59 \pm 0.72\right.$ versus $\left.0.93 \pm 0.48 \mathrm{mmol} . \mathrm{mU} / \mathrm{L}^{2} ; \mathrm{p}=0.006\right)$, higher $\mathrm{CDI}$ index $\left(12.67 \pm 7.04\right.$ versus $\left.6.19 \pm 2.57 \mathrm{~cm}^{2} / \mathrm{kg}\right)$ and higher leptin level $(19.1 \pm 9.6$ versus $7.4 \pm 3.5 \mathrm{ng} / \mathrm{mL}$; $\mathrm{p}=0.028$ ). Conclusions: Arterial hypertension in non-obese women is associated with insulin resistance, central fat distribution and higher leptin levels. Arq Bras Endocrinol Metab. 2009;53(3):340-3.

Keywords

Visceral fat; subcutaneous fat; hypertension; insulin resistance

\section{RESUMO}

Objetivo: Avaliar o impacto da gordura abdominal e resistência à insulina na hipertensão arterial em mulheres não-obesas. Métodos: Foram estudadas 35 mulheres não obesas (NO), com idade entre 35 e 68 anos, separadas em dois grupos de acordo com a presença de hipertensão arterial (PA $\geq 140 \times 90 \mathrm{mmHg}$ ) (HT = hipertenso; NT = normotenso). A leptina foi dosada e um OGTT realizado. Um corte tomográfico foi usado para avaliar a gordura visceral (VF) e subcutânea abdominal (SCF). 0 índice de distribuição central de gordura (CDI) foi proposto para avaliar o impacto da gordura subcutânea abdominal na distribuição central de gordura em pacientes hipertensas. Resultados: Quando comparado ao grupo NT-NO ( $n=17$ ), o grupo HT-NO ( $n=18$ ) mostrou maiores níveis de pressão arterial (sistólica e diastólica), maior área de gordura visceral $\left(84.40 \pm 55.70\right.$ versus $\left.37.50 \pm 23.00 \mathrm{~cm}^{2} ; \mathrm{p}=0.036\right)$, maior área de gordura subcutânea abdominal ( $174.30 \pm 83.00$ versus $\left.79.80 \pm 27.40 \mathrm{~cm}^{2} ; \mathrm{p}=0.030\right)$, maior $\operatorname{HOMAr}(1.59 \pm 0.72$ versus $\left.0.93 \pm 0.48 \mathrm{mmol} . \mathrm{mU} / \mathrm{L}^{2} ; \mathrm{p}=0.006\right)$, maior índice CDI $\left(12.67 \pm 7.04\right.$ versus $\left.6.19 \pm 2.57 \mathrm{~cm}^{2} / \mathrm{kg}\right)$ e maior nível de leptina $(19.1 \pm 9.6$ versus $7.4 \pm 3.5 \mathrm{ng} / \mathrm{mL} ; \mathrm{p}=0.028)$. Conclusões: A hipertensão arterial em mulheres não obesas está associada à resistência à insulina, distribuição central de gordura e altos níveis de leptina. Arq Bras Endocrinol Metab. 2009;53(3):340-3.

Descritores

Gordura visceral; gordura subcutânea; hipertensão; resistência à insulina
\end{abstract}




\section{INTRODUCTION}

The relation between obesity and cardiovascular risk (1-4) has been widely demonstrated and is a common findings of metabolic syndrome (MS). Some studies have shown that arterial hypertension in MS is associated with insulin resistance and central fat distribution, increasing cardiovascular risk $(5,6)$ which may be explained by the elevated lipolitic rate of visceral fat that increases free fatty acid (FFA) levels in portal circulation, leading to insulin resistance and hyperinsulinemia $(3,4)$. The hyperinsulinemia may increase arterial blood pressure by adrenergic or renal mechanisms (7-10).

Other studies have suggested that leptin may increase blood pressure (11-13) and hyperactivity of the reninangiotensin system (RAS) has also been reported (14).

Arterial hypertension in lean subjects may be associated with insulin resistance, mainly peripheral insulin resistance, with higher serum glucose and insulin levels being detected after OGTT.

The aim of this study was to evaluate the association of abdominal fat, insulin resistance and arterial hypertension in non-obese women.

\section{RESEARCH METHODS AND PROCEDURES}

A cross-sectional study including 35 non-obese (NO) women, aging from 35 to 68 was performed from august 2001 to august 2003. Patients were divided into two groups according to the presence of arterial hypertension ( $\mathrm{BP} \geq 140 \times 90 \mathrm{mmHg}$ ) : NT-NO (normotensive non-obese; $\mathrm{n}=17$ ) and HT-NO (hypertensive non-obese; $\mathrm{n}=18$ ). These patients were in treatment with antihypertensive medications discontinued therapy for at least seven days prior to the study. Obesity was defined as body mass index $(\mathrm{BMI}) \geq 30 \mathrm{~kg} / \mathrm{m}^{2}$. Hypertension was defined as either systolic or diastolic office blood pressures $\geq 140 \times 90 \mathrm{mmHg}$.

Exclusion criteria were self-reported diabetes and/or the taking of antihypertensive medications, cardiac, renal or hepatic diseases and secondary arterial hypertension.

The same observer has measured weight, height, waist and hip circumferences. BMI was calculated as weight (kilograms) divided by height (meters) squared. Office blood pressure was based on the average of two seated readings after five minutes of rest. After a 12-hour fasting period, serum glucose level (glucose oxidase) was determined at $0,30,60,90$ and $120 \mathrm{~min}$ utes after a $75 \mathrm{~g}$ oral glucose load. Serum insulin (Auto Delfa, Perkin Elmer) was determined at 0 and 120 min- utes of OGTT. Leptin levels (Elisa, Linco Research, USA) were measured.

Visceral and subcutaneous fat areas (density -50 to $-250 \mathrm{HU}$ ) were obtained by a computed tomography (Picker International) in a single tomographic slice, at the L4-L5 level, expressed in $\mathrm{cm}^{2}$.

Homeostasis model for assessment of insulin resistance index (HOMAr index) was calculated using the formula: fasting glucose $\mathrm{x}$ fasting insulin / $22.5\left(\mathrm{mmol} . \mathrm{mU} / \mathrm{L}^{2}\right)$.

The insulin secretion index (HOMA beta) was calculated using the formula: $20 \mathrm{x}$ fasting insulin/fasting glucose $-3.5(\%)$. Insulin sensitivity index (ISI), proposed by Belfore and cols. (15), was calculated.

We have proposed an index - central fat distribution index (CDI) - calculated by subcutaneous abdominal fat area/total fat mass, obtained by Bioimpedance (Model BIA 101Q; RJL System;USA, ratio $\left(\mathrm{cm}^{2} / \mathrm{kg}\right)$ to evaluate the impact of subcutaneous fat on central fat distribution in hypertensive women. The study was approved by the Institutional Ethics Committee and written informed consent was obtained from all participants.

Statistical analyses were performed using the computer program SPSS 12.0. Data are shown as mean \pm SD. The t-Student test was used to compare the two groups. Multiple linear regression analysis was used to assess the influence of VF, SCF and ISI on office-SBP (systolic blood pressure). Possible associations were assessed through Pearson's correlation coefficients. The level of significance was set at $\mathrm{p}<0.05$.

\section{RESULTS}

A total of 35 women were studied (NT-NO, $\mathrm{n}=17$ and HT-NO, $\mathrm{n}=18$ ). $72 \%$ of the hypertensive non-obese patients were postmenopausal women, while $41 \%$ of the normotensive non-obese patients were postmenopausal women, but it was not a significant difference. Anthropometric measurements, fat areas and central fat distribution index are shown in table 1 .

The hypertensive non-obese group showed greater visceral and subcutaneous fat areas than the normotensive non-obese group (Figure 1).

When compared to the normotensive non-obese patients, the hypertensive non-obese patients had higher leptin levels $(7.4 \pm 3.5$ versus $19.1 \pm 9.6 \mathrm{ng} / \mathrm{mL}$; $\mathrm{p}=0.028)$, higher HOMAr index $(0.93 \pm 0.48$ versus $\left.1.59 \pm 0.72 \mathrm{mmol} / \mathrm{L}^{2} ; \mathrm{p}=0.006\right)$ and lower insulin sensitivity index (ISI) $(1.08 \pm 0.31$ versus $0.82 \pm 0.24$; $\mathrm{p}=0.012)$, as shown in table 2 . 
Table 1. Anthropometric characters, fat areas and central fat distribution index

\begin{tabular}{lcc}
\hline & NT-NO $(\mathbf{n}=\mathbf{1 7})$ & HT-NO $(\mathbf{n}=\mathbf{1 8})$ \\
\hline Age $($ years $)$ & $46.6 \pm 9.1$ & $52.6 \pm 11.0$ \\
BMI $\left(\mathrm{kg} / \mathrm{m}^{2}\right)$ & $23.0 \pm 2.2$ & $23.8 \pm 2.3$ \\
Waist $(\mathrm{cm})$ & $71.3 \pm 7.8$ & $74.5 \pm 9.9$ \\
Hip $(\mathrm{cm})$ & $89.6 \pm 7.4$ & $89.9 \pm 7.9$ \\
WHR & $0.80 \pm 0.008$ & $0.82 \pm 0.06$ \\
VF-CT $\left(\mathrm{cm}^{2}\right)$ & $37.5 \pm 23.0$ & $84.4 \pm 55.7^{\star}$ \\
SCF-CT $\left(\mathrm{cm}^{2}\right)$ & $79.8 \pm 27.4$ & $174.3 \pm 83.0^{*}$ \\
CDI $\left(\mathrm{cm}^{2} / \mathrm{kg}^{*}\right.$ & $6.19 \pm 2.57$ & $12.67 \pm 7.04^{*}$ \\
\hline
\end{tabular}

${ }^{*} p<0.05$ versus NT-NO.

BMl: body mass index; WHR: waist-to-hip ratio; VF-CT: visceral fat area; SCF-CT: subcutaneous abdominal fat area; $\mathrm{CDI}$ : central fat distribution index.

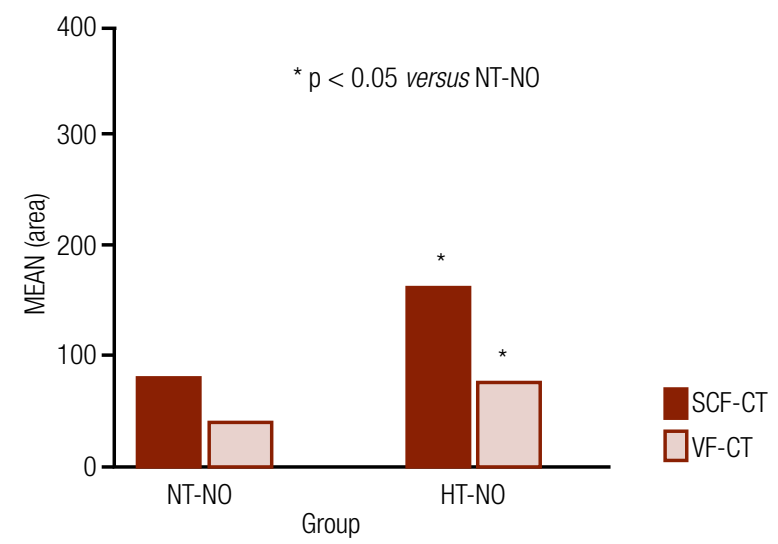

Figure 1. Visceral (VF) and subcutaneous abdominal (SCF) fat areas in groups.

\begin{tabular}{lcc}
\hline \multicolumn{3}{l}{ Table 2. Metabolic parameters according to groups } \\
\hline & NT-NO $(\mathbf{n}=\mathbf{1 7})$ & HT-NO $(\mathbf{n}=\mathbf{1 8})$ \\
\hline Fasting plasma glucose $(\mathrm{mmol} / \mathrm{L})$ & $4.55 \pm 0.46$ & $4.80 \pm 0.33$ \\
2-hr plasma glucose (mmol/L) & $5.13 \pm 0.93$ & $6.20 \pm 1.52$ \\
Fasting insulin (pmol/L) & $31.05 \pm 15.06$ & $53.55 \pm 22.45^{*}$ \\
2-hr insulin (pmol/L) & $249.17 \pm 195.80$ & $358.16 \pm 181.42$ \\
HOMAr (mmol.mU/L $\left.{ }^{2}\right)$ & $0.93 \pm 0.48$ & $1.59 \pm 0.72^{*}$ \\
HOMA $\beta$ (\%) & $0.87 \pm 0.82$ & $1.20 \pm 0.46$ \\
ISI index & $1.08 \pm 0.31$ & $0.82 \pm 0.24^{*}$ \\
Leptin (ng/mL) & $7.4 \pm 3.5$ & $19.1 \pm 9.6^{*}$ \\
\hline
\end{tabular}

${ }^{\star} \mathrm{p}<0.05$ versus NT-NO.

We found inverse correlation between ISI and office systolic blood pressure values $(\mathrm{r}=-0.399 ;[-0.587$; $-0.170] ; p=0.001 ;$ CI 95\%). Positive correlation was found between leptin and subcutaneous abdominal fat area $(\mathrm{r}=0.462 ;[0.050 ; 0.740] ; \mathrm{p}=0.030 ;$ CI 95\%).

Multiple linear regression analysis after adjustment for age and BMI, with office-SBP as the dependent variable, and visceral fat, subcutaneous abdominal fat and ISI as the independent variables, showed that ISI was determinant of office-SBP $\left(\mathrm{R}^{2}=0.106 ; \mathrm{p}=0.033\right.$; Backward).

\section{DISCUSSION}

Hyperinsulinemia has been considered the link between obesity, diabetes and arterial hypertension. As we know, obesity and diabetes mellitus are classical conditions of insulin resistance which has been attributed to higher visceral fat accumulation (2,16-18). Some studies have shown that arterial hypertension in the metabolic syndrome is associated to insulin resistance and central distribution of fat, increasing cardiovascular risk $(3,5,9)$.

Of the hypertensive non-obese and normotensive non-obese patients, 71 and $41 \%$, respectively, were postmenopausal, but it was not a significant difference. Previous studies have demonstrated that postmenopausal status may predispose abdominal fat deposition $(17,19)$ which may be considered a confounder factor in our sample. In fact, the higher central fat deposition found in the hypertensive non-obese women, compared to normotensive non-obese women was associated to higher frequency of patients in the postmenopausal period. These results are in accordance with previous reported data indicating that greater central fat deposition is one the most important factors that determine higher insulin resistance and blood pressure levels. Those data are compatible with central fat distribution index that we have proposed, in which there are normotensive and hypertensive patients, both non-obese, with increase of central fat (increase of both subcutaneous and visceral fat). Thus, this index proposes that, not only visceral fat, but also subcutaneous abdominal fat may also have impact on insulin resistance and on hypertensive condition.

Van Harmelen and cols. showed that leptin is derived mainly from subcutaneous tissue both in obese and non-obese women (11). In this study, higher leptin levels in non-obese hypertensive patients suggest that subcutaneous abdominal fat could produce more leptin than peripheral subcutaneous fat. In fact, a positive correlation was found between subcutaneous abdominal fat and plasma leptin levels. This greater leptin production, followed by increases in sympathetic nervous system activity, could explain the higher insulin resistance and arterial blood pressure in non-obese women with central fat accumulation. Our results have differed from previous ones reported by Ferrannini and cols. (10) who found visceral fat but not subcutaneous fat accumulation in hypertensive subjects. In our study, however, we 
found greater subcutaneous abdominal and visceral fat deposition in hypertensive non-obese subjects.

\section{CONCLUSION}

Arterial hypertension in non-obese women is associated with insulin resistance, central distribution of fat (visceral and subcutaneous abdominal) and higher leptin levels.

Disclosure: This project was supported by Fundação de Amparo à Pesquisa do Estado de São Paulo (Fapesp); the authors disclosed having no conflicts of interest.

\section{REFERENCES}

1. Third Report of The National Cholesterol Education program (NCEP) Expert Panel on Detection, Evaluation and Treatment of High Blood Cholesterol in Adults (Adult Treatment Panel III). Final report. Circulation. 2002;106:3143-421.

2. Wajchenberg BL. Subcutaneous and visceral adipose tissue: their relation to the Metabolic Syndrome. Endocr Rev. 2000;21(6):697-738.

3. Kissebah AH, Vydelingum N, Murray R, Evans DJ, Hartz AJ, Kalkho$\mathrm{ff} \mathrm{RK}$, et al. Relation of body fat distribution to metabolic complications of obesity. Clin Endocrinol Metab. 1982;54(2):254-60.

4. Ferrannini E, Holffner SM, Mitchell BD, Stern MP. Hyperinsulinemia: the key feature of a cardiovascular and metabolic syndrome. Diabetologia. 1991;34(6):416-22.

5. Carr DB, Utzschneider KM, Hull RL, Kodama K, Retzlaff BM, Brunzell JD, et al. Intra-abdominal fat is a major determinant of the National Cholesterol Education Program Adult Treatment panel III. Criteria for the Metabolic Syndrome. Diabetes. 2004;53(8):2087-94.

6. Hayashi T, Boyko EJ, Leonetti DL, McNeely MJ, Newell-Morris L, Kahn SE, et al. Visceral adiposity is an independent predictor of incident hypertension in Japanese Americans. Ann Intern Med. 2004;140(12):992-1000.
7. Anderson EA, Mark AL. The vasodilatador action of insulin. Implications for the insulin hypotesis of hypertension. Hypertension. 1993;21(2):136-41.

8. Faria AN, Ribeiro-Filho FF, Ferreira SRG, Zanella MT. Impact of visceral fat on blood pressure and insulin sensitivity in hypertensive obese women. Obesity Research. 2002;10(12):1203-6.

9. Reaven GM. Role of insulin resistance in human disease. Diabetes. 1988;37(12):1595-607.

10. Sironi AM, Gastaldelli A, Mari A, Ciociaro D, Positano V, Buzzigoli $E$, et al. Visceral fat in hypertension. Influence on insulin resistance and $\beta$-cell function. Hypertension. 2004;44(2):127-33.

11. Van Harmelen, Reynisdottir S, Eriksson P, Thörne A, Hoffstedt J, Lönnqvist $F$, et al. Leptin secretion from subcutaneous and visceral adipose tissue in women. Diabetes. 1998;47(6):913-7.

12. Shek EW, Brands MW, Hall JE. Chronic leptin infusion increases arterial pressure. Hypertension. 1998;31(1 Pt 2):409-14.

13. Dagogo-Jack S, Fanelli C, Paramore D, Brothers J, Landt M. Plasma leptin and insulin relationships in the obese and non-obese humans. Diabetes. 1996;45(5):695-8.

14. Hall JE, Zappe D, Kassab S. Mechanisms of obesity induced hypertension. News Physiol Sci. 1996;11:255-61.

15. Belfiore F, lanello S, Volpicelli G. Insulin sensitivity of blood glucose versus insulin sensitivity of blood free fatty acids in normal, obese and obese-diabetic subjects. Metabolism. 1998;63:134-41.

16. Kelley DE, Thaete L, Trost F, Goodpaster BH. Subdivisions of subcutaneous abdominal adipose tissue and insulin resistance. Am J Physiol Endocrinol Metab. 2000;278(5):941-8.

17. Cefalu WT, Wang ZQ, Werbel S, Bel-Farrow AD, Terry JA, Wang ZQ, et al. Contribution of visceral fat mass to the insulin resistance of aging. Metabolism. 1995;44(7):954-9.

18. Fujioka $S$, Matsuzawa $Y$, Tarui $S$, et al. Contribution of intra-abdominal fat accumulation to the impairment of glucose and lipid metabolism in human obesity. Metabolism. 1987;36(1):54-7.

19. Lamon-Fava S, Wilson PWF, Schaefer EJ. Impact of body mass index on coronary heart disease risk factors in men and women. The Framingham Offspring Study. Arterioscl Thromb Vasc Biol. 1996;16(12):1509-15. 